\title{
Research on the Construction of the Index System of Intellectual Property Protection in the Transnational Operation of Enterprises
}

\author{
Xiao-Hong Zheng ${ }^{1, a, *}$ \\ No. 88 Fuxing Road East, Xiangtan, Hunan Province, \\ China. \\ School of Economics, Hunan Institute of Engineering . \\ Email:374797418@qq.com, \\ *Corresponding author
}

\begin{abstract}
Based on a comprehensive analysis of the current protection of intellectual property rights study at home and abroad, research for enterprise transnational investment, the pattern of trade and the protection of intellectual property is relatively scarce. Therefore, the construction of transnational intellectual property protection index system is particularly important. This article focuses on the introduction of the four factors of intellectual property protection: patent status, human capital, the legal system environment and market competitive advantage, elucidates how to set up the index system with four variables as the core, and aims to explore a new method for the study of the protection of intellectual property rights issue in the transnational operation of enterprises.
\end{abstract}

Keywords-Intellectual property protection (IPP) system, Intellectual property protection index system, Enterprise internationalization management.

\section{INTRODUCTION}

At present, most of the domestic and foreign scholars use the theoretical analysis and data analysis to describe the characteristics of the concept of intellectual property protection, its driving factors and the promotion measures. However, the empirical quantitative research and case studies related to comprehensive factors are also very few. From the current point of view, whether it is from an empirical study or from the perspective of normative research, experts and scholars at home and abroad have reached a consensus that the intellectual property protection system can promote the enterprise, national and global economic growth, and achieved abundant research results. But existing literature studies are generally located in the protection of intellectual property rights and the scale of export trade, intellectual property protection and economic growth, and research for transnational operations of the enterprise investment, the pattern of trade and the protection of intellectual property of relative field are rarely few. Therefore, it is of the urgent practical significance to construct the index system of intellectual property protection in the transnational operation of enterprises.

\author{
Yu-Hui Shi ${ }^{2, b}$ \\ No. 88 Fuxing Road East, Xiangtan, Hunan Province, \\ China. \\ School of Management, Hunan Institute of Engineering \\ Email: Hnxtsyh@sina.com
}

\section{FOUR FACTORS OF THE IPP INDEX SYSTEM IN THE ENTERPRISE TRANSNATIONAL OPERATION}

The global high technology transfer tends to be realized by adopting the mode of investment, trade, technology licensing or contract management. So it is very important to study the intellectual property protection influence mechanism on the multinational business smooth operation. In the process of transnational operation of enterprises, intellectual property rights specifically relate to patent, trademark, trade secret, high technology, copyright and other proprietary resources. Because these proprietary resources are scarce, it is necessary to pay the economic price for obtaining or using them. As the enterprise's market competition is inevitable, How to use the intellectual property to gain competitive advantage in the market, which is certainly linked with the problem of how to protect IP. And the protection of intellectual property rights must be closely related with human capital full of technological innovation ability, protection of intellectual property rights while at the same time impacted by the social protection of intellectual property rights legal system environment. Through using some theory related to the protection of intellectual property rights, reviewing literatures and combining working practice experience with the investigation and study achievements on the enterprises, I construct the dimension system of IPP in Enterprises Transnational Operation.And the following is the dimension table of IPP System in Enterprises Transnational Operation:

\section{A. Human Capital}

In the era of rapid development of science and technology, knowledge economy, human resource is the key resource of maintaining competitive advantage, is the elements or means of creating wealth and welfare, which reflects human resource stock, not the reward. Human resource is the source of getting wealth, human capital is the wealth itself which is produced through investment with the characteristics of capital, so it is necessary to consider the issue of income. Only by coordinating all aspects of human resource management, human resources can be transformed into human capital, and economic benefits can be improved. Who has more human capital, who will be able to win in the fierce competition in the market. 
Human capital is usually divided into two accumulation patterns: one is not dependent on the school education, but dependent on the production work experience accumulated, emphasizes "learning by doing" access to human capital accumulation, so as to improve the production efficiency; the second is dependent on school education, out of production, each person's intelligence and skills in the economic activities can be improved, and leads to the accumulation of human capital.

The sub-level rating indicators related to human capital in the enterprise transnational management of IPP:

- $\quad$ the proportion of highly educated people = highly educated personnel / total enterprise staff x $100 \%$. The proportion of highly educated talent reflects that the highly educated people mastering IPRP knowledge and techniques occupy the proportion of the total number of enterprises on the post, the ratio of more highly educated intellectual property talents is bigger, can bring more high-quality human resources for the enterprise, to promote the technological innovation of enterprises in a certain extent.

- the proportion of technical personnel $=$ the technical personnel / enterprise staff X100\%.

- Technical personnel proportion reflects the proportion of intellectual property and technology R \& D personnel among the enterprises staff on the post. The change of enterprise technology R \& D personnel will affect the company's high-tech research and invention.

- the average number of invention patent application= number of the patents inventors / total application (Licensing) patents number. The average number of patents for the invention is measured by the number of inventors who are involved in each patent. The number of active inventors can be obtained by using the patent application.

- $\quad$ the proportion of patents inventor =total number of authorized application patent inventor / total professionals. It reflects the proportion of patent inventors occupying the industry professionals, the greater the ratio, the more adequate human resources of the industry's invention.

- the number of core inventors is the number of major inventors of patents in some industry. The core inventors is usually the technical backbone of a certain industry who are more involved in the development of technology and patent applications and obtain more, you can obtain the relevant patents data through the statistic number of patents inventors.

Knowledge itself has a social complexity, its characteristics of difficult to imitating can promote technological innovation of the organization (Akintoye and Chinyio, 2005) ${ }^{[2]}$. Under the background of the globalization of the world economy, knowledge resources is often scattered in various organizations or regional scope, enterprises need high-quality human capital to integrate the scattered knowledge resources (including internal and external resources integration, tacit and explicit knowledge of knowledge integration, and the formation of an interaction network for the facilitating exchange of information and knowledge (Vachon and Klassen, 2008) ${ }^{[3]}$ to reduce resource acquisition costs and obtain the success of technical innovation (Renzl, 2008) ${ }^{[4]}$. So the level of human capital has become an important factor in the protection of intellectual property rights.

\section{B. Patent Status}

"Introduction, digestion, absorption and re-innovation" is the different levels embodying independent innovation, research and development intensity. The "autonomy" in the autonomy IP means the owner of IP has the exclusive rights to use, the rights can be independent innovation right, right bought by spending money, right by introducing cooperative, or right by others free donation and many other varieties of ways.

As an important indicator to measure the strength of an enterprise's R \& D, the total amount of patent application and authorization occupies an important position.

The sub-rating indicators related to the patent status in the enterprise transnational management of intellectual property protection:

- (1) the amount of patent ownership mainly reflects the total number of patents owned by enterprises, and the number of patents reflects the technological innovation capability of enterprises. The patents enterprises have are mainly self-developed patents and the purchased patents, but does not include the invalid patent and the patent given up. In the transnational flow of worldwide patent and licensing fees, transnational corporations in developed countries account for $98 \%$ of the total income. In addition, in capital formation, technological progress, employment, business management, multinational corporation's international production has a great impact on the host country production. The number of patents owned can also be seen from the number of patents and licensing costs.

- (2) the patent growth rate $=$ [the application (Licensing) patent - the previous application (Licensing) patent] / the previous application (Licensing) patent. Patent growth rate $=$ Patent Application (license) growth rate / statistics periods. Patent average growth rate reflects the change of enterprises patents, if the enterprise patent applications increase in a period of time, so that enterprises have some breakthrough in technology and can be given the corresponding support, promote the technological innovation of the enterprises. In the calculation of the patent growth rate indicators, there is a time span, this time span can be short or long, which is decided by different technical fields. For example, the steel industry technology life cycle is longer, the time span is three years or more. In the electronic technology industry, the time span is 
shorter, generally one year for the cycle.

(3) the proportion of the invention and the new invention patent $=$ the number of the invention patent / utility model patent number. According to the invention and the new invention, the proportion index of the invention reflects the patent quality level. The traditional patent indicators include four weighted two indicators, such as the patent licensing rate, the technical scope, the country range, the reference frequency and so on. The weight coefficient is determined by the expert evaluation. The traditional patent quality index can be effective in the accuracy of the patent warning evaluation, but considering the actual implementation of index selection, so the proportion of the invention and the new invention patent are adopted to substitute the evaluation indicators.

(4) the average length of patents maintenance = the maintenance period of the patent / total number of valid patents. The average maintenance period of the patent is the life of the patent, which reflects the level of the patent value and the enterprise's innovation ability. Patent protection is authorized each year and a large amount of money should be spent, some patent with no market value attracts no enterprises contributions, as abandonment of a patent. Only when the income of the patent produced is greater than the annual fee, the enterprise will continue to pay the patent fee. Therefore, in general, the patent maintaining a relatively long period is generally of higher value, or relates to the enterprise's strategic layout of the patents.

(5) the percentage of core patent family = the number of an enterprise patent design applications on the core patent race / the number of the industry's core patent family x $100 \%$. The core of the patent family share index reflects the ratio between the number of an enterprise patent applications on the core patent family and the number of the industry's core patent family. When an enterprise is in the high technology innovation patent applications, if the patent family coordinated with the industry core patent family, then the enterprise is likely to be in the industry leading position and formulated to be leader of the industry technical standards, and thus obtain technical advantage and occupy most of the market share.

- (6) Possessing rate of the core patents = the core patents an enterprise applied / the total patents an enterprise applied x $100 \%$. It reflects how many patents one enterprise applied are related to the industry's core technology. If the majority patents enterprises applied are the core patents in the industry, which reveals the enterprise's leading position is at a visible technical level in the industry.

\section{Competitive Advantage}

The operational control of power is valued in the enterprises transnational operation, reflected in the control of the shares, which aims mainly to exclude local enterprises competition in the host countries, make skills and the abilities contributed to the investment process be able to get a full return on the market, market defects caused by the protection system of the intellectual property right leads to some multinational companies with their own professional and technical competitive advantage to obtain monopoly or oligopoly status, and to occupy a dominant position in the market competition.

The competitive advantage caused by IPP of enterprises transnational operation establishes in the competitive advantage of high level -- namely "products differentiated competitive advantage", this advantage is built through sustained investment and innovation in equipment, technology, management and marketing and create more differentiated products in line with customer demand.

The sub-level rating indicators related to competitive advantage:

- $\quad$ (1) technical width = the number of authorized patents in the enterprise / the number of Licensed Patents in the industry which are both involved in the patent classification number. Breadth of technical index reflects the enterprise scope of patent technology possessed. If technology width index of enterprises is large, so enterprises are in the leading position of the technology industry, as well as the technological level of the enterprise, and the enterprise patent strategy in related industries. The object of intellectual property protection market competition advantage concerned is mainly the technical width.

- (2) the greater the number of new technology, the greater the potential for the development of technology in the field of technology, but also may be a precursor to the development of new products, or to make a good breakthrough in the professional and technical aspects of the enterprise.

- $\quad$ (3) operating income growth rate for the period = revenue for the period- the operating income for the last period / operating income of the last period $\mathrm{X} 100 \%$.

The resource based theory holds that the competitive advantage of the enterprise comes from the possession of scare and valuable resources. When enterprise resource rich in value, character in scarcity, difficult to imitate and substitute, the sustainable competitive advantage of enterprises forms, the economic performance of enterprises sources in the exclusive resources, because it can bring for the enterprise the rate of return higher than the average.

\section{Legal System Environment}

The second level rating indicators related to the legal system environment:

- (1) similar patents means the number of similar patents applied and authorized, the number of similar patents other applicants applying for or licensing.

- (2) the same claim is the requirements for the same rights and interests of the patent of other patent applicants to apply or authorize in the patent 
application

Any fruit of independent innovation is not equal to one's owning. Only subject to legal protection, the invention can not become a well-known technique free to use. Free use of the invention creation does not have big benefits to improve the competitiveness of enterprises; only inventions by the legal protection, timely application for patent protection is exclusive, has great benefit to improve the core competitiveness of enterprises. The essence of intellectual property is the tool of economic competition, the protection of intellectual property legal system is to further enhance the competitiveness of enterprises, based on the integrity of the orderly competition.

The evaluation of the legal system and the principle of governance depends on the three levels: the degree of perfection of legislation, the intensity of law enforcement, the public awareness of the legal system. Multi-National Corporation's cross international behavior choice needs to consider the constraints and incentives of a country's policy. The environment of the legal system of intellectual property protection has the same constraints and incentives influence on the international nature of the Multi-National Corporations.

Some scholars believe that the study of multinational corporations entry mode is the essence of the firm boundary problem research, because the entry mode is a kind of system arrangement of resources allocation implementation which makes the enterprise products, technology, human capital, management measures and other resources flow across borders into other countries. And the four dimensional indexes of the system of intellectual property protection --human capital, patent status, market competition, legal environment from the above four aspects have a great impact on the enterprise's entry mode.

\section{CONCLUSION}

The above four affected factors/variables (patent status, human capital, the legal system environment and market competitive advantage) of intellectual property protection are introduced, and the four variables actual core index system is elucidated in the essay aiming to build the foundation of the research on multinational enterprises in intellectual property protection and the multinational high technology transfer methods.

\section{ACKNOWLEDGEMENT}

This research is funded by: Hunan Provincial Science and Technology Plan Project, Project No.:2015ZK3044; Hunan Provincial Philosophy and Social Science Foundation, Project No.:14YBA125; Hunan Institute of Engineering Doctoral Fund Project, Project No.:11118

\section{REFERENCES}

[1] Chen Zhi-xun. Construction and Empirical Study on the Evaluation System of Patent Early Warning [D]: [Master's degree thesis of Shanxi University of Finance and Economics] Datong: Shanxi University of Finance and Economics, 2010(In Chinese)

[2] Akintoye A, Chinyio E. Private finance initiative in the healthcare sector: trends and risk assessment. Engineering, Construction and Architectural Management, 2005,12(6):602-616

[3] Vachon S, Klassen R D. Environmental management and manufacturing performance: the role of collaboration in the supply chain. Production Economics, 2008,111(2): 299-315

[4] Renzl B. Trust in management and knowledge sharing: the mediating effects of fear and knowledge documentation. Omega,2008,36(2): 206-220 
TABLE 1: IPR SYSTEM IN ENTERPRISES TRANSNATIONAL OPERATION

\begin{tabular}{|c|c|}
\hline Four dimensions of IPRP & Specific Index (16) \\
\hline Human capital & $\begin{array}{l}\text { (1)the highly educated talents and technical personnel proportion, } \\
(2,3) \text { patent average invention number and proportion, } \\
\text { (4) the proportion of patents inventor, } \\
\text { (5) the number of core inventors }\end{array}$ \\
\hline Patent status & $\begin{array}{l}\text { (1) the amount of patent ownership } \\
\text { (2) the patent growth rate } \\
\text { (3) the proportion of the invention and the new invention patent } \\
\text { (4) the average length of patents maintenance } \\
\text { (5) the percentage of core patent family } \\
\text { (6) Possessing rate of the core patents }\end{array}$ \\
\hline Market competitive advantage & $\begin{array}{l}\text { (1)technology width } \\
\text { (2)new technology features number } \\
\text { (3) sales growth rate }\end{array}$ \\
\hline Legal system environment & $\begin{array}{l}\text { (1) similar patents, } \\
\text { (2) the same rights requirements. [1] }\end{array}$ \\
\hline
\end{tabular}

